\title{
Comparison of physical and mechanical properties of river sand concrete with quarry dust concrete
}

\author{
${ }^{1}$ Hyginus E. Opara, ${ }^{2}$ Uchechi G. Eziefula, ${ }^{3}$ Bennett I. Eziefula \\ ${ }^{1}$ Department of Civil Engineering, Imo State University, Owerri, Nigeria \\ ${ }^{2}$ School of Engineering Technology, Imo State Polytechnic, Umuagwo, Nigeria \\ ${ }^{3}$ Department of Mechanical Engineering, Federal University of Technology, Owerri, Nigeria \\ e-mail: ${ }^{1}$ heopara@yahoo.co.uk, ${ }^{2}$ uchechi.eziefula@yahoo.com, ${ }^{3}$ ikeziefula@gmail.com
}

\begin{abstract}
This study compared the physical and mechanical properties of river sand concrete with quarry dust concrete. The constituent materials were batched by weight. The water-cement ratio and mix ratio selected for the experimental investigation were 0.55 and 1:2:4, respectively. The specimens were cured for 7, 14, 21 and 28 days. Slump, density and compressive strength tests were carried out. The results showed that river sand concrete had greater density and compressive strength than quarry dust concrete for all curing ages. At 28 days of curing, river sand concrete exceeded the target compressive strength by $36 \%$, whereas quarry dust concrete was less than the target compressive strength by $12 \%$. Both river sand concrete and quarry dust concrete for the selected water/cement ratio and mix ratio are suitable for non-structural applications and lightly-loaded members where high strength is not a prerequisite.
\end{abstract}

Key words: density, compressive strength, concrete, river sand, quarry dust

\section{Introduction}

Concrete is the most important construction material in the world and around 15 billion tons are annually produced [1]. Sustainable development is geared towards ensuring that the present generation can meet its needs without compromising the ability of future generations to meet their needs [2]. In order to make concrete a more sustainable construction material, efforts are being directed towards research on utilisation of alternative recycled materials as whole or partial replacement of constituent materials in concrete.

Sand and gravel represent the most widely consumed raw material on earth after water, and between $64-75 \%$ of aggregate mined each year is used for making concrete [3]. Natural sand has been conventionally used as fine aggregate in concrete. Natural sand possesses rounded or cubical particles with smooth surface texture which provide good workability in concrete [4]. Sand occupies around $35 \%$ volume in a concrete mix [5]. The growing use of river sand as a raw material in production of concrete and other industrial applications means that depletion of deposits of natural sand is inevitable. Reduction in natural sand deposits, as well as the dredging and excavation processes used in obtaining natural fine aggregate, may cause negative environmental impact such as non-reversible landscape changes and threat to river 
ecosystems [3]. Owing to the environmental hazards associated with mining natural sand, authorities in some areas have placed restrictions using measures such as legislation and taxation [6-9]. A possible alternative to natural sand in production of concrete is quarry dust, a by-product of rock quarrying. Quarry dust has particle sizes in the range of $0.05-5 \mathrm{~mm}$ and forms around 20-25\% of the total output of rock crushing [6,10]. Large volumes of quarry dust are produced by rock quarrying industries which cause environmental problems. Only a little fraction of the quarry dust is used as filler in wearing courses of asphalt pavements [9]. Using quarry dust as an alternative to river sand in concrete can provide solutions to problems of waste management, environmental degradation and depletion of natural resources.

Investigations have been conducted on utilisation of quarry dust as total or partial replacement of river sand in concrete. At 28 days of curing, partial replacement of fine aggregate with 20$50 \%$ quarry dust content resulted to optimum compressive strength of concrete for several mix ratios and water/cement ratios [11-16]. Researchers have also used quarry dust as total replacement of sand in concrete. Quarry dust concrete at curing age of 28 days exhibited higher compressive strength than river sand concrete [6,17-18]. However, a few studies reported lower compressive strength for quarry dust concrete in comparison with river sand concrete $[11,14,19]$. Reports on workability and density of quarry dust concrete are also varied. This paper compared the workability, density and compressive strength of quarry dust concrete with river sand concrete using the same mix ratio and water/cement ratio. The same quantity and type of cement, water and coarse aggregate were used in the present study.

\section{Materials and Methods}

\subsection{Constituent Materials}

Ordinary Portland cement of grade 42.5R manufactured to [20] standards was used. River sand and quarry dust were the fine aggregates used in the experimental investigation. River sand was dredged from Otamiri River located in Owerri, Imo State while quarry dust was obtained from a quarry plant in Ebonyi State. Crushed granite of $20 \mathrm{~mm}$ nominal size was obtained from a quarry plant in Ebonyi State and used as coarse aggregate. Potable water was used for washing the aggregates, as well as mixing and curing the concrete specimens.

\subsection{Testing of Aggregates}

The physical properties and particle size distribution of the fine aggregates were determined. The tested physical properties of the both fine and coarse aggregates were specific gravity and density. Fineness modulus was determined for both river sand and quarry dust, whereas aggregate impact and Los Angeles abrasion of the crushed granite were tested.

\subsection{Preparation and Testing of Concrete Specimens}

Concrete mix ratio was batched by weight. The mix ratio and water-cement ratio selected for the investigation were 1:2:4 and 0.55, respectively. Mix ratio 1:2:4 is a specified prescribed mix which corresponds to normal concrete strength [21]. Two groups of concrete specimens were produced: mix containing $100 \%$ quarry dust as fine aggregate and another mix 
containing $100 \%$ river sand which served as control. No additives were used. The constituent materials were mixed by hand. The cement and aggregates were first thoroughly mixed in dry state. Water of prescribed quantity was gradually added to the dry mixture with continuous mixing. Concrete cubes of size $150 \times 150 \times 150 \mathrm{~mm}$ were produced and cured. Specimens were left in the moulds for 24 hours to set before being demoulded and cured. The specimens were cured by immersion in a water tank for 7, 14, 21, and 28 days.

The slump of fresh concrete, density of hardened concrete, and compressive strength of hardened concrete were tested. Slump, density and compressive strength tests of the specimens were carried out in accordance with [22], [23] and [24], respectively. Density and compressive strength results were obtained for the concrete cubes at 7, 14, 21, and 28 days of curing. The density and compressive strength are represented by the average values of three concrete cubes for each curing age.

\section{Results and Discussion}

\subsection{Aggregates}

The particle size distribution of river sand and quarry dust are shown in Fig. 1. The coefficient of curvature, $C_{c}$ of river sand is 0.96 and the uniformity coefficient, $C_{u}$ of river sand is 2.11 . The corresponding values for quarry dust are 0.8 and 5.45, respectively. A well-graded soil has a $C_{u}$ value of 5 or more and a $C_{c}$ value between 1 and 3 [25]. The values indicate that the river sand has a small range of particle size whereas the quarry dust has a wider range of particle sizes. Both aggregates fall into zone 2 of the grading requirements for fine aggregates and are suitable for producing concrete [26].

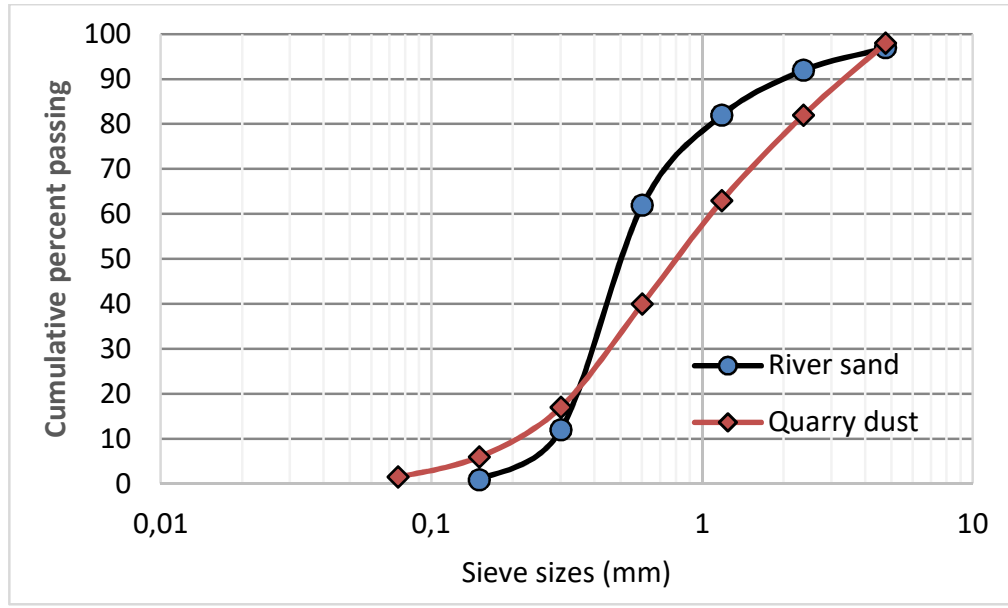

Figure 1: Particle size distribution curves for river sand and quarry dust

The results of physical properties of the fine aggregates are shown in Table 1, while the physical and mechanical properties of the coarse aggregate are given in Table 2 . The values obtained for specific gravity of the aggregates were within the range for normal weight aggregates although quarry dust slightly exceeded the maximum limit stated in Neville and 
Brooks [27]. It should be noted that the limits for specific gravity given in Tables 1 and 2 are not strict requirements for aggregates, but only represent the range for specific gravity of most normal weight aggregates used in producing concrete. The bulk densities of the river sand, quarry dust and granite are similar to values reported in previous investigations $[9,28]$. Fineness modulus obtained for the fine aggregates indicate that river sand has relatively finer grains whereas quarry dust has coarser grains.

Table 1. Physical properties of aggregates

\begin{tabular}{|c|c|c|c|}
\hline Property & River sand & Quarry dust & Acceptance limit for concrete \\
\hline Specific gravity & 2.64 & 2.76 & $2.6-2.8[4,27]$ \\
\hline Fineness modulus & 2.54 & 2.96 & $2.2-3.2[4,29]$ \\
\hline Density $\left(\mathrm{kg} / \mathrm{m}^{3}\right)$ & 1570 & 1360 & - \\
\hline
\end{tabular}

Table 2. Physical and mechanical properties of coarse aggregate

\begin{tabular}{|c|c|c|}
\hline Property & Granite & Acceptance limit for concrete \\
\hline Specific gravity & 2.68 & $2.6-2.8[4,27]$ \\
\hline Density $\left(\mathrm{kg} / \mathrm{m}^{3}\right)$ & 1545 & - \\
\hline Aggregate impact value (\%) & 15.10 & $\leq 25-45 \%[4,30]$ \\
\hline Los Angeles abrasion value (\%) & 18.30 & $\leq 30-50 \%[4]$ \\
\hline
\end{tabular}

\subsection{Slump}

Quarry dust concrete and river sand concrete had slump values of $80 \mathrm{~mm}$ and $60 \mathrm{~mm}$, respectively. Thus, fresh concrete mix of quarry dust concrete showed lower workability than river sand concrete for 1:2:4 mix ratio and water-cement ratio of 0.55 . The higher slump observed for quarry dust may be due to higher sand content in quarry dust. Since the water content and cement content were constant, workability is expected to be lower in the concrete mix containing finer particles of fine aggregate. The quarry dust used in the study had higher percentage of coarse sand grains than river sand. Increase in fines content generally leads to lower slump if the water content remains the same. Finer particles have higher surface area which requires more amount of water for wetting. The slump of both quarry dust concrete and river sand concrete fell within the range of $25-100 \mathrm{~mm}$, indicating medium workability [31].

\subsection{Density}

The Fig. 2 shows the density results of river sand concrete and quarry dust concrete. The bulk density of normal weight concrete usually ranges from $2200-2600 \mathrm{~kg} / \mathrm{m}^{3}$ [27]. The density of all the specimens fell within the range of normal weight concrete. The densities increase with curing age, with 7 days corresponding to the lowest density and 28 days attaining the highest density. There was an increase in $7.6 \%$ between the densities of the 7-day and 28-day curing age of river sand concrete. For the quarry dust concrete, the corresponding increase was $4.8 \%$. The increase in the density is attributed to compaction effect of hydration process on the internal matrix of the concrete specimens owing to curing. 


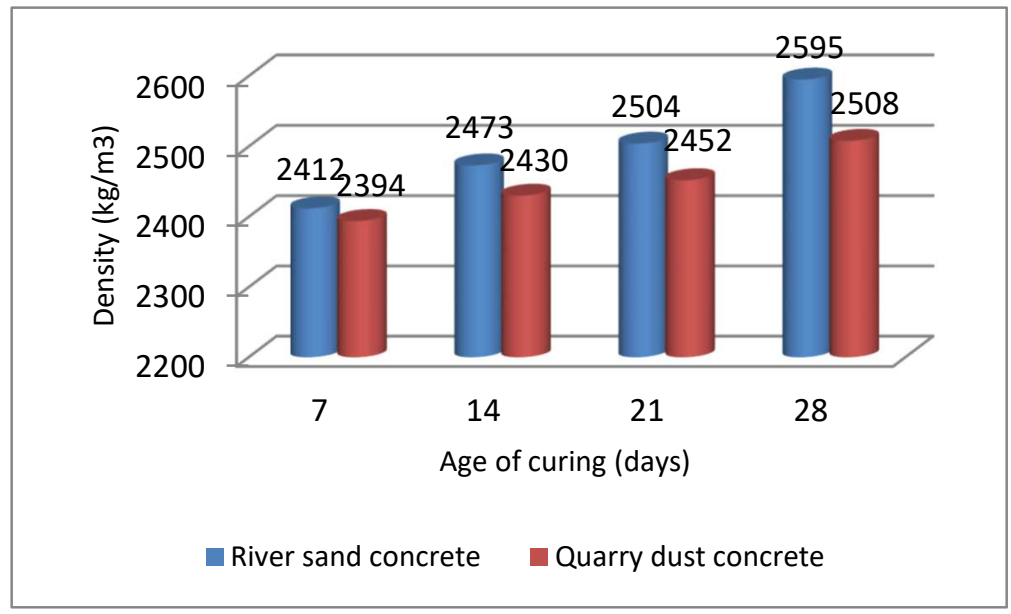

Figure 2: Density development of concrete specimens with age of curing

River sand concrete attained higher densities than quarry dust concrete for all ages of curing. The higher density of river sand concrete can be as a result of higher density of the river sand in relation to the quarry dust. The density of river sand concrete and quarry dust concrete are within the nominal value of $24 \mathrm{kN} / \mathrm{m}^{3}$ (i.e. $2,446 \mathrm{~kg} / \mathrm{m}^{3}$ ) for traditional normal weight concrete assumed in BS 8110-1 [32]. The density of 28-day river sand concrete and 28-day quarry dust concrete were higher than the value assumed in [32] by $6.1 \%$ and $2.5 \%$, respectively. This implies that river sand concrete and quarry dust concrete would produce members with similar self-weight to traditional concrete.

\subsection{Compressive Strength}

The trend in attainment of compressive strength of both river sand concrete and quarry dust concrete specimens is illustrated in Fig. 3. Both river sand concrete and quarry dust concrete had similar compressive strength development with increase in age of curing, with river sand concrete having higher values of compressive strength for all curing ages. This is due to increased amount of hydration products with the longer curing age. The 7-day compressive strength for river sand concrete and quarry dust concrete were $68 \%$ and $65 \%$ of the 28 -day compressive strength, respectively. The respective values obtained for quarry dust concrete in [13], [15] and [18] were $80 \%, 81 \%$ and 58\%. The ratio of the 7-day strength to 28-day strength of the present study was closer to the reported value in [18] which used the same water-cement ratio and mix ratio. Factors which affect the strength attainment of concrete include aggregate grading and size, curing conditions and cement content. The compressive strength of concrete at 7 days is usually within the range of $60-80 \%$ of the compressive strength at 28 days for conventional concrete cured under standard conditions [27].

For mixes intended to achieve $21 \mathrm{~N} / \mathrm{mm}^{2}$ target strength at 28 days, the compressive strength of river sand concrete exceeded the target strength by $36 \%$. However, the compressive strength of the quarry dust concrete at 28 days of curing was less than the target strength by $12 \%$. The lower compressive strength of quarry dust concrete could be attributed to the higher 
proportion of silt/clay particles in quarry dust compared with river sand. Presence of very fine particles in aggregate tends to interfere with the bond between cement paste and aggregate, which causes reduction in strength.

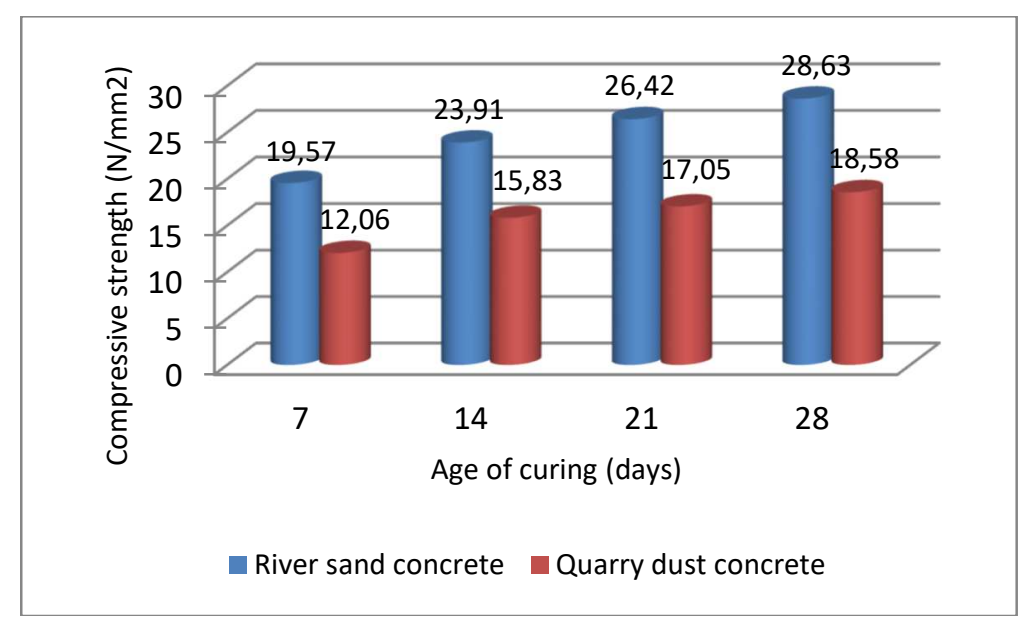

Figure 3: Compressive strength development of concrete specimens with age of curing

\section{Conclusion}

The properties of river sand concrete and quarry dust concrete have been compared in terms of slump, density and compressive strength. For the 1:2:4 mix ratio and 0.55 water-cement ratio, river sand concrete gave higher density and compressive strength than quarry dust concrete. However, quarry dust concrete had more workability. Both river sand concrete and quarry dust concrete can be applied in non-structural members and lightly-loaded members where high strength is not a prerequisite. The river sand concrete is also suitable for production of normal reinforced concrete.

\section{References}

[1] Frigione, M. (2015). If the buildings were made of bottles... Edorium Journal of Waste Management, 1, 20-22. DOI: 10.5348/W01-2015-4-ED-4.

[2] Elliot, J.A. (2006). An introduction to sustainable development (3rd ed.). Oxford, UK: Routledge.

[3] UNEP Global Environmental Alert Service (2014). Sand, rarer than one thinks. Retrieved July 3, 2017, from: https://europa.eu/capacity4dev/unep/document/unepglobal-environmental-alert-service-geas-sand-rarer-one-thinks

[4] Shetty, M.S. (2012). Concrete technology: Theory and practice (6th revised ed.). New Delhi, India: S. Chand.

[5] Akinboboye, F.A.O., Adegbesan, O.O., Ayegbusi, O.A. \& Oderinde, S.A. (2015). Comparison of the compressive strength of concrete produced using sand from different 
sources. International Journal of Academic Research in Environment and Geography, 2(1), 6-16. DOI: 10.6007/IJAREG/v2-i1/1792.

[6] Rajapaksha, R.W.C.N. \& Sooriyaarachchi, H.P. (2009). Feasibility of quarry dust to replace river sand as fine aggregate of concrete. Engineer: Journal of the Institution of Engineers, Sri Lanka, 42(4), 30-37. DOI: 10.4038/engineer.v42i4.7031.

[7] Söderholm, P. (2011). Taxing virgin natural resources: Lessons from aggregates taxation in Europe. Resources, Conservation and Recycling, 55(11), 911-922. DOI: 10.1016/j.resconrec.2011.05.011.

[8] Bahn-Walkowiak, B., Bleischwitz, R., Distelkamp, M. \& Meyer, M. (2012). Taxing construction minerals: a contribution to a resource-efficient Europe. Mineral Economics, 25(1), 29-43. DOI: 10.1007/s13563-012-0018-9.

[9] Anya, C.U. \& Osadebe, N.N. (2015). Effect of partial replacement of sand with quarry dust on the structural characteristics of sandcrete blocks. Nigerian Journal of Technology, 34(4), 679-684. DOI: 10.4314/njt.v34i4.3.

[10] Agbede, O.I. \& Joel, M. (2004). Suitability of quarry dust as partial replacement for sand in hollow block production. Nigerian Journal of Engineering Research Development, 3(4), 33-37.

[11] Joel, M. (2010). Use of crushed granite fine as replacement to river sand in concrete production. Leonardo Electronic Journal of Practices and Technologies, 17, 85-96.

[12] Nagabhushana \& bai, H.S. (2011). Use of crushed rock powder as replacement of fine aggregate in mortar and concrete. Indian Journal of Science and Technology, 4(8), 917922. DOI: $10.17485 / \mathrm{ijst} / 2011 / \mathrm{v} 4 \mathrm{i} 8 / 30896$.

[13] Balamurugan, G. \& Perumal, P. (2013). Behaviour of concrete on the use of quarry dust to replace sand - An experimental study. IRACST - Engineering Science and Technology: An International Journal, 3(6), 776-781.

[14] Manguriu, G.N., Karugu, C.K., Oyawa, W.O., Abuodha, S.O. \& Mulu, P.U. (2013). Partial replacement of natural river sand with crushed rock sand in concrete production. Global Engineers \& Technologists Review, 3(4), 7-14.

[15] Rajput, V.S., Pandey, S., Jain, D. \& Saxena, A.K. (2014). Use of quarry fine as partial replacement of concrete as a replacement of fine aggregate in concrete (evaluation of workability and compressive strength). International Journal for Scientific Research \& Development, 2(7), 161-164.

[16] Prakash, K.S. \& Rao, C.H. (2016). Study on compressive strength of quarry dust as fine aggregate in concrete. Advances in Civil Engineering, Article ID 1742769, 5 pp. DOI:10.1155/2016/1742769.

[17] Ilangovana, R., Mahendrana, N. \& Nagamanib, K. (2008). Strength and durability properties of concrete containing quarry rock dust as fine aggregate. ARPN Journal of Engineering and Applied Sciences, 3(5), 20-26.

[18] Chijioke, C., Igwegbe, W., Ibearugbulem, O., Okoye, P. \& Oke, M. (2014). Comparing the compressive strengths of concrete made with river sand and quarry dust as fine 
aggregates. International Letters of Natural Sciences, 20, 179-189. DOI:10.18052/www.scipress.com/ILNS.20.179.

[19] Sivakumar, A. \& Prakash, M. (2011). Characteristic studies on the mechanical properties of quarry dust addition in conventional concrete. Journal of Civil Engineering and Construction Technology, 2(10), 218-235.

[20] Standards Organisation of Nigeria. (2003). Quality standard for ordinary Portland cement - Part 1: Composition, specification and conformity criteria for common cements. NIS 444-1. Lagos.

[21] Asiedu, R.O. (2016). Using lateritic gravel as all-in aggregate for concrete production. Journal of Engineering, Design and Technology, 15(3), 305-316. DOI 10.1108/JEDT01-2016-0001.

[22] British Standards Institution. (1983). Testing concrete - Part 102: Method for determination of slump. BS 1881-102. London.

[23] British Standards Institution. (1983). Testing concrete - Part 114: Methods for determination of density of hardened concrete. BS 1881-114. London.

[24] British Standards Institution (1983). Testing concrete - Part 116: Method for determination of compressive strength of concrete cubes. BS 1881-116. London.

[25] McKinlay, D.G. (1996). Soils. In N. Jackson \& R.K. Dhir (Eds.), Civil engineering materials (5th ed.) (pp. 349-447). Basingstoke, UK: Palgrave.

[26] Standards Organisation of Nigeria. (2004). Standards for sandcrete block. NIS 87. Lagos.

[27] Neville, A.M. \& Brooks, J.J. (2010). Concrete technology (2nd ed.). Essex, UK: Pearson Education.

[28] Eziefula, U.G., Opara, H.E. \& Anya, C.U. (2017). Mechanical properties of palm kernel shell concrete in comparison with periwinkle shell concrete. Malaysian Journal of Civil Engineering, 29(1), 1-14.

[29] American Concrete Institute. (1999). Aggregates for concrete. ACI Education Bulletin E1-99.

[30] British Standards Institution. (1992). Specification for aggregates from natural sources for concrete. BS 882. London.

[31] Dhir, R.K. \& Jackson, N. (1996). Concrete. In N. Jackson \& R.K. Dhir (Eds.). Civil engineering materials (5th ed.) (pp. 161-298). Basingstoke, UK: Palgrave.

[32] British Standards Institution. (1997). Structural use of concrete - Part 1: Code of practice for design and construction. BS 8110-1. London. 